ISSN (Print) : 1693-0738

ISSN (Online) : 2714-5549

Innofarm:Jurnal Inovasi Pertanian Vol. 22 (1), April 2020

\title{
KAJIAN MACAM DAN DOSIS PUPUK ORGANIK TERHADAP PERTUMBUHAN KETELA POHON (Manihot esculenta Crantz.)
}

\author{
AnnisaWitular*, JM. Sri Hardiatmi, KharisTriyono \\ FakultasPertanian, UniversitasSlametRiyadi, Surakarta \\ *E-mail:witularannisa@gmail.com
}

\begin{tabular}{|c|c|}
\hline Info Artikel & Abstract \\
\hline $\begin{array}{l}\text { Keywords: } \\
\text { Organic Fertilizer, Dosage } \\
\text { of Organic Fertilizer, } \\
\text { Growth Cassava. }\end{array}$ & $\begin{array}{l}\text { Study the Types and Dosage of Organic Fertilizers of Cassava } \\
\text { (Manihot esculenta Crantz). The research to observe the } \\
\text { development of cassava due to the influence of cassava based on } \\
\text { organic fertilizer. This research was conducted from October } 2019 \\
\text { to January 2020, in the Experimental Garden of the Faculty of } \\
\text { Agriculture, Slamet Riyadi University, Surakarta. This study used } \\
\text { a Completely Randomized Design (CRD) method with } 1 \text { treatment, } \\
\text { namely type and dose of organic fertilizers and obtained } 10 \\
\text { combinations treatments and each was repeated } 3 \text { times. From the } \\
\text { research data, analysis of variance will be carried out nd then the } \\
\text { real difference test will be countinued with the real Honestly } \\
\text { Significant Difference test at the 5\% level. In this observation } \\
\text { observed included } 8 \text { parameters: shoot height, longest root length, } \\
\text { number of roots, number of leaves, fresh weight of planted roots, } \\
\text { dry weight of planted roots, fresh weight of planting buds, and dry } \\
\text { weight of planting buds. The results showed that (1) effect of kinds } \\
\text { and dosages of organic fertilizer the effect very apparent in the } \\
\text { parameters of the number of planted leaves, number of planted } \\
\text { roots, longest root length, dry weight of planted roots, fresh weight } \\
\text { of planted shoots and dry weight of planted shoots. Significantly } \\
\text { affected the shoot height parameters. No significant effect is found } \\
\text { on the parameters of the fresh root weight of the crop. (2) The } \\
\text { dosage of } 1.9 \text { kg / polybag (MD7) fertilizer application gave the } \\
\text { best results on the dry weight of shoots, } 378 \text { grams. }\end{array}$ \\
\hline & Abstrak \\
\hline $\begin{array}{l}\text { Kata kunci: } \\
\text { Pupuk Organik, Dosis } \\
\text { Pupuk Organik, } \\
\text { Pertumbuhan Ketela } \\
\text { Pohon. }\end{array}$ & $\begin{array}{l}\text { Kajian Macam dan Dosis Pupuk Organik Terhadap Pertumbuhan } \\
\text { Ketela Pohon (Manihot esculenta Crantz). Penelitian bertujuan } \\
\text { untuk mengamati perkembangan ubi kayu karena pengaruh macam } \\
\text { dan dosis Pupuk organik. Penelitian ini dilaksanakan mulai bulan } \\
\text { Oktober } 2019 \text { sampai Januari 2020, di Kebun Percobaan Fakultas } \\
\text { Pertanian Universitas Slamet Riyadi Surakarta. Metode yang } \\
\text { digunakan dalam penelitian Rancangan Acak Lengkap (RAL) } 1 \\
\text { faktorial yaitu macam dan dosis pupuk organic diperoleh } 10 \text { macam } \\
\text { perlakuan dan masing-masing diulang } 3 \text { kali. Dari data hasil } \\
\text { penelitian akan dilakukan Analisis Sidik Ragam lalu dilanjut } \\
\text { pengujian Beda Nyata Jujur } 5 \% \text {. Dalam pengamatan ini mengamati } \\
8 \text { parameter meliputi Tinggi Tunas,Panjang Akar } \\
\text { Terpanjang,Jumlah Akar ,Jumlah Daun,Berat Segar Akar } \\
\text { pertanaman,Berat Kering Akar pertanaman, Berat Basah Tunas } \\
\text { pertanaman dan Berat Kering Tunas pertanaman. Hasil penelitian }\end{array}$ \\
\hline
\end{tabular}

Annisa Witular, JM. Sri Hardiatmi, Kharis Triyono. 
menunjukkan bahwa (1) Pelakuan pengaruh macam dan dosis pupuk organik berpengaruh sangat nyata pada parameter jumlah akar pertanaman, jumlah daun pertanaman, panjang akar terpanjang, berat segar tunas pertanaman, berat kering tunas pertanaman dan berat kering akar pertanaman. Berpengaruh nyata pada parameter tinggi tunas. Pengaruh tidak nyata terdapat pada parameter berat segar akar pertanaman. (2) Perlakuan Pupuk Kascing Dosis 1,9 Kg/Polybag (MD7) memberikan hasil terbaik pada berat kering tunas yaitu 378 gram..

\section{PENDAHULUAN}

Ketela pohon adalah umbi-umbian yang mempunyai kandungan karbohidrat cukup tinggi.Semua bahan yang mengandung karbohidrat dapat digunakan sebagai bahan baku penghasil alkohol. Karbohidrat diubah menjadi gula oleh enzim yang terdapat pada ragi, kemudian gula diubah oleh mikroorganisme menjadi alkohol.

Ketela Pohon berasal dari benua Amerika, tepatnya di Brazil dan Paraguay. Penyebarannya keseluruh negara termasuk Indonesia. Singkong ditanam di wilayah Indonesia sekitar tahun 1810 yang diperkenalkan oleh orang Portugis dari Brazil.Singkong merupakan tanaman yang penting bagi Negara beriklim tropis seperti Nigeria, Brazil, Thailand, dan juga Indonesia. Keempat Negara tersebut merupakan Negara penghasil singkong terbesar di dunia (Soelistijono, 2006).

Varietas adalah spesies tanaman yang memiliki karakteristik genotype tertentu, seperti bentuk, pertumbuhan tanaman, daun, bunga dan biji yang dapat membedakan dengan jenis atau spesies tanaman lain, jika diperbanyak tidak mengalami perubahan.

Menurut Purnomo dan Purnawati (2010), potensi hasil ubi kayu ditentukan oleh sifat dari bagian tanaman di atas tanah. Percepatan perkembangan ubi kayu ditentukan oleh sifat genetis dan factor lingkungan. Penggunaan bibit yang bermutu tinggi dan sehat merupakan syarat utama untuk mempertahankan populasi tanaman per satuan luas dan hasil yang tinggi.

Salah satu cara untuk meningkatkan produktivitas ketela pohon yaitu penggunaan pupuk. Pupuk organic adalah pupuk yang sebagian besar atau seluruhnya terdiri dari bahan organik yang berasal dari tumbuhan dan hewan yang telah melalui proses rekayasa. Menurut Pemmy Tumewu, Carolus P.

Paruntu, dan Tommy D. Sondakh (2015), bahwa pemupukan berpengaruh terhadap hasil ubi kayu.

\section{BAHAN DAN METODE}

Penelitian menggunakan bahan-bahan yang meliputi: singkong varietas gajah, pupuk organik (pupuk kandang sapi, Pupuk hijau \& Pupuk kascing), tanah latosol. Lalu alat yang digunakan meliputi: polybag $(60 \mathrm{~cm} \times 60 \mathrm{~cm})$, cangkul, angkong, gembor, benang, meteran, alat tulis, timbangan elektrik dan oven. 
ISSN (Print) : 1693-0738

ISSN (Online) : 2714-5549

Innofarm:Jurnal Inovasi Pertanian Vol. 22 (1), April 2020

\section{HASIL DAN PEMBAHASAN}

Tabel 1.Rata-rata pengamatan akibat perlakuan macam dan dosis pupuk organic terhadap pertumbuhan ubi kayu (Manihot esculenta crantz.)

\begin{tabular}{|l|c|c|c|c|c|c|c|c|}
\hline Perlakuan & $\begin{array}{c}\text { Tinggi } \\
\text { Tunas } \\
\text { (cm) }\end{array}$ & $\begin{array}{c}\text { Jumlah } \\
\text { Daun } \\
\text { (Helai) }\end{array}$ & $\begin{array}{c}\text { Jumlah } \\
\text { Akar } \\
\text { (Helai) }\end{array}$ & $\begin{array}{c}\text { Panjang } \\
\text { Akar } \\
\text { Terpanjang } \\
\text { (Helai) }\end{array}$ & $\begin{array}{c}\text { BS } \\
\text { Akar } \\
\text { (gr) }\end{array}$ & $\begin{array}{c}\text { BK } \\
\text { Akar } \\
\text { (gr) }\end{array}$ & $\begin{array}{c}\text { BS Tunas } \\
\text { (gr) }\end{array}$ & $\begin{array}{c}\text { BK } \\
\text { Tunas } \\
\text { (gr) }\end{array}$ \\
\hline MD0 & $149,3 \mathrm{a}$ & $51,3 \mathrm{ab}$ & $128 \mathrm{~b}$ & $64 \mathrm{c}$ & $6 \mathrm{a}$ & $2 \mathrm{c}$ & $631 \mathrm{~b}$ & $113 \mathrm{abc}$ \\
\hline MD1 & $76,9 \mathrm{a}$ & $32,3 \mathrm{ab}$ & $77,8 \mathrm{ab}$ & $33,7 \mathrm{abc}$ & $6,6 \mathrm{a}$ & $1,5 \mathrm{bc}$ & $101,3 \mathrm{a}$ & $16,5 \mathrm{a}$ \\
\hline MD2 & $102,1 \mathrm{a}$ & $49 \mathrm{ab}$ & $86 \mathrm{ab}$ & $32 \mathrm{abc}$ & $4 \mathrm{a}$ & $1 \mathrm{abc}$ & $633 \mathrm{~b}$ & $139 \mathrm{bc}$ \\
\hline MD3 & $134,3 \mathrm{a}$ & $44 \mathrm{ab}$ & $77 \mathrm{ab}$ & $56 \mathrm{abc}$ & $6 \mathrm{a}$ & $1 \mathrm{abc}$ & $700 \mathrm{bc}$ & $151 \mathrm{bc}$ \\
\hline MD4 & $125 \mathrm{a}$ & $38,67 \mathrm{ab}$ & $88,67 \mathrm{ab}$ & $36,8 \mathrm{abc}$ & $6,3 \mathrm{a}$ & $0,64 \mathrm{ab}$ & $972,15 \mathrm{~cd}$ & $52,78 \mathrm{ab}$ \\
\hline MD5 & $120 \mathrm{a}$ & $34,67 \mathrm{ab}$ & $78,3 \mathrm{ab}$ & $29,6 \mathrm{abc}$ & $5,3 \mathrm{a}$ & $0,9 \mathrm{abc}$ & $163 \mathrm{a}$ & $31,4 \mathrm{a}$ \\
\hline MD6 & $69,27 \mathrm{a}$ & $26 \mathrm{a}$ & $41 \mathrm{a}$ & $20 \mathrm{a}$ & $3 \mathrm{a}$ & $0,45 \mathrm{a}$ & $101 \mathrm{a}$ & $12 \mathrm{a}$ \\
\hline MD7 & $141 \mathrm{a}$ & $72 \mathrm{~b}$ & $56 \mathrm{ab}$ & $36 \mathrm{abc}$ & $5 \mathrm{a}$ & $1 \mathrm{abc}$ & $1474 \mathrm{~d}$ & $378 \mathrm{c}$ \\
\hline MD8 & $166,3 \mathrm{~b}$ & $62,3 \mathrm{~b}$ & $75,7 \mathrm{ab}$ & $41,5 \mathrm{abc}$ & $6,4 \mathrm{a}$ & $1,6 \mathrm{c}$ & $680,4 \mathrm{bc}$ & $177,9 \mathrm{c}$ \\
\hline MD9 & $167,67 \mathrm{~b}$ & $45,3 \mathrm{ab}$ & $109 \mathrm{~b}$ & $49,2 \mathrm{abc}$ & $8,5 \mathrm{a}$ & $1,7 \mathrm{c}$ & $1172,6 \mathrm{~cd}$ & $172,5 \mathrm{c}$ \\
\hline
\end{tabular}

Keterangan : Rata-rata yang di ikuti huruf yang sama berarti berbeda tidak nyata pada taraf $5 \%$ uji BNJ.

\section{Tinggi Tunas $(\mathrm{cm})$}

Penggunaan Pupuk Kascing Dosis 5,7 kg/polybag (MD9) dengan rata-rata tinggi tunas 167,67 $\mathrm{cm}$ berbeda nyata jika dibandingkan dengan perlakuan Pupuk Hijau Dosis 5,7 kg/polybag (MD6) dengan rata-rata tinggi tunas $69,27 \mathrm{~cm}$.

2. Jumlah Daun (helai)

Pupuk Kascing Dosis 1,9 Kg/Polybag (MD7) dengan jumlah daun pertanaman rata-rata 72 helai, berbeda sangat nyata jika dibandingkan dengan perlakuan Pupuk Hijau Dosis 5,7 Kg/Polybag (MD6) dengan jumlah daun pertanaman rata-rata 26 daun.

Pupuk organik yang memakai sistem vermi kompos dapat meningkatkan pertumbuhan panjang tanaman (Talkah, 2010). Hal ini diduga karena pupuk vermikompos sampah organik mengandung unsur hara nitrogen.

3. Jumlah Akar (helai)

Perlakuan Tanpa Pupuk (kontrol) (MD0) dengan rata-rata jumlah akar pertanaman 128 helai sangat berbeda nyata jika dibandingkan dengan perlakuan Pupuk Hijau Dosis 5,7 Kg/Polybag (MD6) dengan rata-rata jumlah akar pertanaman 41 helai.

Penggunaan polybag pada sistem pertumbuhan tanaman ubi kayu dapat menghambat perkembangan akar, sehingga perkembangannya tidak optimal.

4. Panjang Akar Terpanjang $(\mathrm{cm})$

Perlakuan Tanpa Pupuk (kontrol) (MD0) dengan rata-rata panjang akar $64 \mathrm{~cm}$ berbeda sangat nyata jika dibandingkan dengan perlakuan Pupuk Hijau Dosis 5,7 Kg/Polybag (MD6) dengan rata-rata panjang akar $20 \mathrm{~cm}$.

\section{Berat Segar Akar (gr)}

Pupuk Kascing Dosis 5,7 Kg/Polybag (MD9) dengan rata-rata berat segar akar pertanaman 8,5 gram berbeda tidak nyata dibanding perlakuan Pupuk Hijau Dosis 5,7 Kg/ Polybag (MD6) dengan berat segar akar pertanaman 3 gram. Tinggi rendahnya stek tergantung dari mutus tek, kelembaban, suhu, lingkungan, dan intensitas cahaya. Dengan adanya karbohidrat yang lebih tinggi dapat mempengaruhi berat segar suatu tanaman (Dwijoseputro, 1990) 


\section{Berat Kering Akar (gr)}

Perlakuan Tanpa Pupuk (kontrol) (MD0) rata-rata 2 gram berbeda sangat nyata jika dibandingkan dengan perlakuan Pupuk Hijau Dosis 5,7 Kg/Polybag (MD6) dengan berat kering akar pertanaman rata-rata 0,45 gram.

Penerapan vermicomposts di lapangan meningkatkan kualitas tanah dengan meningkatkan aktivitas mikroba dan biomassa mikroba yang merupakan komponen kunci dalam siklus hara dan produksi zat pengatur tumbuh. (Norman at.al., 2005).

7. Berat Segar Tunas (gr)

Pada berat segar tunas pertanaman Pupuk Kascing Dosis 1,9 Kg/Polybag (MD7) 1474gram sangat berbeda nyata dibanding perlakuan Pupuk Hijau Dosis 5,7 Kg/Polybag (MD6) dengan rata-rata 101 gram. Peningkatan tinggi tunas pasti di ikuti oleh peningkatan berat segar tunas karena berat segar tunas berhubungan dengan tinggi tunas.

8. Berat Kering Tunas (gr)

Berat kering tunas pertanaman tertinggi ditunjukan pada perlakuan Pupuk Kascing Dosis 1,9 Kg/Polybag (MD7) 378gram, yang dimana sangat berbeda nyata kalau dibanding perlakuan Pupuk Hijau Dosis 5,7 Kg/Polybag (MD6) dengan berat kering tunas pertanaman rata-rata 12 gram.

Berat kering tunas dapat di gunakan sebagai indicator pertumbuhan pada tanaman. Berat kering sangat mencerminkan akumulasi dari senyawa organik yang telah disentensiskan dari senyawa anorganik. Pada dasarnya mengamati pertumbuhan tanaman melalui berat kering jauh lebih baik dibandingkan dengan mengamati melalui berat basah karena tanaman yang masih basah angka yang di dapat terlalu fluktuasi. Menurut Gardner er.al, (1991) berat tanaman yang masih segar mempengaruhi kadar air dan kelembaban tanaman, kadar air bisa tinggi karena kemasukan air yang terlalu banyak.

\section{KESIMPULAN}

1. Pelakuan pengaruh macam dan dosis pupuk organik berpengaruh sangat nyata pada parameter jumlah akar pertanaman, jumlah daun pertanaman, panjang akar terpanjang, , berat segar tunas pertanaman, berat kering tunas pertanaman dan berat kering akar pertanaman. Berpengaruh nyata pada parameter tinggi tunas. Pengaruh tidak nyata terdapat pada parameter berat segar akar pertanaman.

2. Perlakuan Pupuk Kascing Dosis 1,9 Kg/Polybag (MD7) memberikan hasil terbaik pada berat kering tunas yaitu 378 gram.

\section{DAFTAR PUSTAKA}

Dwijoseputro., 1990. Pengantar Fisiologi Tumbuhan. Jakarta : Gramedia.

Norman Q. Arancon and Clive A. Edwards. 2005. Effects of Vermicomposts on Plant Growth. Paper presented during the International Symposium Workshop on Vermi Technologies for Developing Countries. The Ohio State University, Columbus, USA.

Purnomo dan Heni Purnawati. 2010. Budidaya 8 Jenis Tanaman Pangan Unggul. Jakarta : Penebar Swadaya. 137 halaman.

Soelistijono. 2006. Tanaman Singkong. Jakarta : Penebar Swadaya.

Talkah, A. 2010. Kajian Pengolahan Limbah Jengkok Tembakau Industri Rokok sebagai Pupuk Organik. Disertasi. Program Doktor Ilmu Pertanian. Fak. Pertanian. Universitas Brawijaya. Malang.

Tumewu, Pemmy.,Carolus P. Paruntu, dan Tommy D. Sondakh. 2015. Hasil Ubi Kayu (Manihot esculenta Crantz) Terhadap Perbedaan Jenis Pupuk. Jurnal LPPM Bidang Sains dan Teknologi. 2 (2). 